\title{
A comparison of sexual behaviour and risk behaviour for HIV infection between women in three clinical settings
}

\author{
K W Radcliffe, T Tasker, B A Evans, A Bispham, M Snelling
}

\begin{abstract}
Objective-To compare sexual behaviour and HIV risk behaviour between women in three clinical settings and to investigate the effect of socio-economic status and ethnic origin upon these behaviours. Subjects and Methods-A questionnaire was administered to 1,950 women attending clinics for genitourinary medicine (GUM) family planning and termination of pregnancy (TOP), all in inner London. Results-A quarter of women attending the GUM and TOP clinics were not using any regular form of contraception. Differences in the median numbers of sexual partners in the past year (1-2) and over lifetime (4-6) between the three groups were slight. Amongst the women in all three groups: more than half $(54 \cdot 8-64 \cdot 9 \%)$ had had a non-regular partner in the preceding twelve months; fewer than one-fifth $(10 \cdot 4-17 \cdot 1 \%)$ reported always using condoms with their regular partners, and fewer than two-fifths (31.3-39.7\%) always used them with their non-regular partners; approximately one in five women (18.6-23.9\%) reported one or more major HIV risk behaviours. Some parameters of sexual behaviour were found to be influenced by socio-economic status and/or ethnic origin.
\end{abstract}

Conclusions-The behaviour of women attending these three clinics is very similar. Women attending clinics for family planning or termination of pregnancy need advice on sexually transmitted diseases and HIV infection, and women attending genitourinary medicine or termination clinics need advice on contraception. Closer integration between disciplines is required to provide a comprehensive sexual health service for women.

(Genitourin Med 1993;69:441-445)

\section{Introduction}

The transmission of sexually transmitted diseases (STD) is dependent on human sexual behaviour and the more information that is available about such behaviour the greater will be the understanding of their epidemiology.

Investigation into this intimate domain of human behaviour is fraught with difficulty. The information sought can only be obtained directly from the subjects either in a face-toface interview or by administering a questionnaire; this may be rendered inaccurate because of errors of memory or because of conscious or unconscious distortion in the answers given by the subject to questions regarded as embarrassing.

Another problem is in choosing the population to be studied. Attempting to describe the sexual behaviour of the general population is problematic because of both sampling error and low response rates $65 \%$ in a major recent study ${ }^{1}$ ) leading to a possible participation bias.

A different approach is to survey patients attending clinics of one kind or another. Such studies have obtained excellent response rates in the order of $84 \cdot 3-97 \cdot 5 \% .^{2-6}$ However, since patients attending such clinics are selected populations it may be misleading to extrapolate from them to the population at large. Conversely, in the real world health workers do deal with selected clinic populations, so the results of such studies are directly applicable to clinical practice.

To increase the representativeness of its findings, this study was carried. out in three clinic settings.

\section{Subjects and methods}

Consecutive new female patients attending a department of genitourinary medicine (GUM), a family planning clinic (FPC) and a clinic for termination of pregnancy (TOP) were asked to complete a questionnaire while they were in the department. The questionnaire was self-administered, with assistance where required for comprehension. All three clinics were in close proximity to each other within the same district health authority in inner London. The study was conducted concurrently in the three clinics between November 1989 and February 1991. Questions were asked concerning: contraception; sexual behaviour; specified behaviours known to be associated with the transmission of HIV (use of intravenous drugs, intercourse with a user of intravenous drugs, intercourse with a bisexual male, intercourse with a haemophiliac, intercourse with someone from sub-Saharan Africa); history of specified sexually transmitted diseases (pelvic inflammatory disease, genital herpes, genital warts, gonorrhoea, chlamydial infection, trichomoniasis, syphilis). Women were asked about numbers of both regular and non-regular partnèrs and were left to make subjective definitions of these terms. 
The following demographic data were also recorded: age; marital status; ethnic origin; usual occupation. Occupation was used as a measure of socio-economic status, subjects being assigned to one of four categories. Class 1 included managers, professionals and employees in occupations ancillary to the professions. Class 2 denoted those in non-manual or "white-collar", skilled occupations and Class 3 included all skilled, semi-skilled and unskilled manual employees. Patients for whom no information was available, or whose answers could not easily be classified, were categorised as "unclassifiable". This included students and the unemployed. Data were analysed using the SPSS package. Tests of significance used were the chi square test and the one-way analysis of variance. Statistically significant results were regarded as those with a $\mathrm{p}$ value $<0.05$

\section{Results}

Questionnaires were completed by 917 women in the GUM group, 611 in the FPC group and 422 in the TOP group. Refusal rates were low in each group, being $5.5 \%$, $2.0 \%$ and $2.1 \%$ respectively. The refusal rate for the GUM group was significantly higher than for the FPC group $(p=0.001)$ or the TOP group $(p=0.009)$.

Comparison between clinic populations

(i) Demographics (table 1)

The mean age of the TOP group was significantly lower than that of the GUM or FPC groups ( $p<0.0001$ in both cases). There were significantly more single women in the GUM group than in the FPC group $(p=$ 0.003 ). There were significantly more women from socio-economic class 1 in the FPC group than in the GUM group $(p=0.03)$, or in the TOP group $(p<0.0001)$.

The FPC group contained the highest proportion of Caucasian women and the TOP group the most Afro-Caribbean women. The GUM group was intermediate in both cases. These differences were significant $(p<0.05)$ for all three clinic populations with respect to both ethnic groups. The number of subjects belonging to other ethnic groups was too small for meaningful comparisons to be made.

Table 1 Demographics

\begin{tabular}{|c|c|c|c|}
\hline & $\begin{array}{l}G U M \\
n=917\end{array}$ & $\begin{array}{l}F P C \\
n=611\end{array}$ & $\begin{array}{l}\text { TOP } \\
n=422\end{array}$ \\
\hline $\begin{array}{l}\text { Age } \\
\text { Mean (years) } \\
\% \text { under } 40 \text { years }\end{array}$ & $\begin{array}{l}27 \cdot 1 \\
92 \cdot 2\end{array}$ & $\begin{array}{l}27 \cdot 3 \\
93 \cdot 3\end{array}$ & $\begin{array}{l}25 \cdot 4 \\
97 \cdot 2\end{array}$ \\
\hline $\begin{array}{l}\text { Marital status (\%) } \\
\text { Single }\end{array}$ & $81 \cdot 7$ & $75 \cdot 3$ & 79.5 \\
\hline $\begin{array}{l}\text { Socio-economic status (\%) } \\
\text { Class } 1 \\
\text { Class } 2 \\
\text { Class } 3 \\
\text { Unclassifiable }\end{array}$ & $\begin{array}{l}30 \cdot 8 \\
21 \cdot 9 \\
16 \cdot 1 \\
31 \cdot 2\end{array}$ & $\begin{array}{l}38 \cdot 3 \\
26 \cdot 4 \\
15 \cdot 7 \\
19 \cdot 6\end{array}$ & $\begin{array}{r}7 \cdot 8 \\
19 \cdot 2 \\
15 \cdot 2 \\
57 \cdot 8\end{array}$ \\
\hline $\begin{array}{l}\text { Ethnic origin (\%) } \\
\text { Caucasian } \\
\text { Afro-Caribbean } \\
\text { Other }\end{array}$ & $\begin{array}{r}81 \cdot 3 \\
15 \cdot 4 \\
3 \cdot 3\end{array}$ & $\begin{array}{l}85 \cdot 67 \\
9 \cdot 7 \\
4 \cdot 7\end{array}$ & $\begin{array}{r}67 \cdot 8 \\
24 \cdot 5 \\
7 \cdot 7\end{array}$ \\
\hline
\end{tabular}

Table 2 Contraception

\begin{tabular}{lcll}
\hline & GUM & FPC & TOP \\
& $n=917$ & $n=611$ & $n=422$ \\
\hline OCP (\%) & $40 \cdot 8$ & $60 \cdot 4$ & $28 \cdot 1$ \\
Condom (\%) & $19 \cdot 3$ & $12 \cdot 8$ & $38 \cdot 9$ \\
Diaphragm (\%) & $4 \cdot 7$ & $10 \cdot 7$ & $5 \cdot 2$ \\
IUD (\%) & $5 \cdot 1$ & $9 \cdot 5$ & $1 \cdot 8$ \\
Other (\%) & $4 \cdot 8$ & $3 \cdot 4$ & $1 \cdot 0$ \\
None (\%) & $25 \cdot 3$ & $3 \cdot 1$ & $25 \cdot 0$ \\
\hline
\end{tabular}

(ii) Contraception (table 2)

Significantly more $(\mathrm{p}<0.05)$ FPC women used the oral contraceptive pill (OCP), the diaphragm and the intrauterine device (IUD) than in the other two groups. Amongst the TOP women, significantly more relied on the condom for contraception than in the other two groups $(p<0.05)$.

(iii) Sexual behaviour, HIV risk-behaviours and past STD (table 3)

Coitarche (age at first sexual intercourse) was significantly younger in the TOP group than in the other two groups $(p<0.05)$. Women in the GUM group had had a greater median number of sexual partners in the previous year, and over their lifetimes, than had women in the other two groups $(p<0.05)$.

Orogenital sex (fellatio), both penetration and to ejaculation, had been practised by significantly more women in the FPC group than in the GUM group $(p=0.002$ and $p=0.001$ respectively), and by more GUM women than TOP women $(p<0.0001$ for both activities). Significantly more FPC subjects had been anally penetrated than had those in the GUM group $(p=0.04)$, but there were no significant differences between the number of women in all three groups who had practised anal intercourse to ejaculation.

Significantly fewer women in the GUM group reported having had one or more nonregular sexual partners within the past year than did women in either the FPC group $(p<0.0001)$ or the TOP group $(p<0.0001)$.

Table 3 Sexual behaviour, HIV risk-behaviours and past STD

\begin{tabular}{|c|c|c|c|}
\hline & $\begin{array}{l}G U M \\
n=917\end{array}$ & $\begin{array}{l}F P C \\
n=611\end{array}$ & $\begin{array}{l}\text { TOP } \\
n=422\end{array}$ \\
\hline Coitarche (mean) & $17 \cdot 4$ years & 17.9 years & $17 \cdot 3$ years \\
\hline $\begin{array}{l}\text { Mean (median) number of } \\
\text { partners } \\
\text { in past year } \\
\text { in lifetime }\end{array}$ & $\begin{array}{r}1.97(2) \\
11 \cdot 15(6)\end{array}$ & $\begin{array}{l}1 \cdot 51(1) \\
7 \cdot 61(5)\end{array}$ & $\begin{array}{l}1.55(1) \\
6.82(4)\end{array}$ \\
\hline $\begin{array}{l}\text { Orogenital sex (ever) } \\
\text { penetration (\%) } \\
\text { ejaculation (\%) }\end{array}$ & $\begin{array}{l}79 \cdot 4 \\
42 \cdot 9\end{array}$ & $\begin{array}{l}86 \cdot 1 \\
52 \cdot 5\end{array}$ & $\begin{array}{l}63 \cdot 1 \\
28 \cdot 5\end{array}$ \\
\hline $\begin{array}{l}\text { Anal intercourse (ever) } \\
\text { penetration (\%) } \\
\text { ejaculation (\%) }\end{array}$ & $\begin{array}{r}15 \cdot 8 \\
8 \cdot 1\end{array}$ & $\begin{array}{r}20 \cdot 2 \\
9 \cdot 6\end{array}$ & $\begin{array}{r}15 \cdot 4 \\
7 \cdot 3\end{array}$ \\
\hline $\begin{array}{l}\text { Non-regular partner(s) } \\
\text { in past year }(\%)\end{array}$ & $54 \cdot 8$ & 68.9 & $67 \cdot 9$ \\
\hline $\begin{array}{l}\text { Condom use } \\
\text { With regular partner(s) } \\
\text { always (\%) } \\
\text { never (\%) }\end{array}$ & $\begin{array}{l}12 \cdot 1 \\
48 \cdot 7\end{array}$ & $\begin{array}{l}10 \cdot 4 \\
47 \cdot 5\end{array}$ & $\begin{array}{l}17 \cdot 1 \\
35 \cdot 0\end{array}$ \\
\hline $\begin{array}{l}\text { With non-regular partner(s) } \\
\text { always }(\%) \\
\text { never }(\%)\end{array}$ & $\begin{array}{l}31 \cdot 3 \\
28 \cdot 9\end{array}$ & $\begin{array}{l}39.5 \\
23.7\end{array}$ & $\begin{array}{l}39 \cdot 7 \\
24 \cdot 6\end{array}$ \\
\hline $\begin{array}{l}\text { One/more HIV } \\
\text { risk-behaviours (\%) }\end{array}$ & 23.9 & $18 \cdot 6$ & 20.7 \\
\hline One/more past STD (\%) & $32 \cdot 5$ & $21 \cdot 7$ & $23 \cdot 1$ \\
\hline
\end{tabular}


The TOP women said that they always used condoms with their regular partners(s) significantly more often than did women in the GUM $(p=0.027)$ or FPC groups ( $p=$ 0.004 ), and that they never used condoms significantly less often than did the other two groups $(p<0.0001$ and $p=0.0002$ respectively). However, there were no significant differences in condom use with non-regular partners between the three groups.

Significantly more women in the GUM group reported an HIV risk-behaviour than

Table 4 Behaviour by socio-economic group

\begin{tabular}{|c|c|c|c|}
\hline & $\begin{array}{l}\text { Class } 1 \\
(n=569)\end{array}$ & $\begin{array}{l}\text { Class } 2 \\
(n=492)\end{array}$ & $\begin{array}{l}\text { Class } 3 \\
(n=347)\end{array}$ \\
\hline Coitarche (mean) & $18.04 \mathrm{yrs}$ & $17 \cdot 59 \mathrm{yrs}$ & $17 \cdot 39$ yrs \\
\hline $\begin{array}{l}\text { Number of partners (mean) } \\
\text { in past year } \\
\text { in lifetime }\end{array}$ & $\begin{array}{r}1 \cdot 81 \\
11 \cdot 25\end{array}$ & $\begin{array}{l}1 \cdot 69 \\
9 \cdot 36\end{array}$ & $\begin{array}{l}1 \cdot 76 \\
8 \cdot 23\end{array}$ \\
\hline $\begin{array}{l}\text { Orogenital sex (ever) } \\
\text { penetration (\%) } \\
\text { ejaculation (\%) }\end{array}$ & $\begin{array}{l}90 \cdot 8 \\
56 \cdot 8\end{array}$ & $\begin{array}{l}81 \cdot 4 \\
45 \cdot 9\end{array}$ & $\begin{array}{l}74 \cdot 9 \\
38 \cdot 4\end{array}$ \\
\hline $\begin{array}{l}\text { Anal intercourse (ever) } \\
\text { penetration (\%) } \\
\text { ejaculation (\%) }\end{array}$ & $\begin{array}{r}19 \cdot 5 \\
9 \cdot 5\end{array}$ & $\begin{array}{r}17.4 \\
8.9\end{array}$ & $\begin{array}{r}18 \cdot 3 \\
6 \cdot 8\end{array}$ \\
\hline $\begin{array}{l}\text { Non-regular partner(s) } \\
\text { in past year }(\%)\end{array}$ & $39 \cdot 3$ & $37 \cdot 8$ & $39 \cdot 3$ \\
\hline \multicolumn{4}{|l|}{ Condom-use } \\
\hline $\begin{array}{l}\text { With regular partner(s) } \\
\text { always }(\%) \\
\text { never }(\%)\end{array}$ & $\begin{array}{l}12 \cdot 4 \\
44 \cdot 5\end{array}$ & $\begin{array}{r}8 \cdot 4 \\
49 \cdot 0\end{array}$ & $\begin{array}{r}9 \cdot 5 \\
50 \cdot 8\end{array}$ \\
\hline $\begin{array}{l}\text { With non-regular partner(s) } \\
\text { always }(\%) \\
\text { never }(\%)\end{array}$ & $\begin{array}{l}38 \cdot 6 \\
22 \cdot 3\end{array}$ & $\begin{array}{l}35 \cdot 6 \\
27 \cdot 3\end{array}$ & $\begin{array}{l}31 \cdot 3 \\
26 \cdot 0\end{array}$ \\
\hline \multicolumn{4}{|c|}{ One/more HIV risk-behaviours (\%) } \\
\hline $\begin{array}{l}\text { One/more past STD (\%) } \\
\text { genital herpes (\%) } \\
\text { trichomoniasis (\%) }\end{array}$ & $\begin{array}{r}29 \cdot 9 \\
5 \cdot 9 \\
7 \cdot 2\end{array}$ & $\begin{array}{r}29 \cdot 5 \\
2 \cdot 7 \\
5 \cdot 4\end{array}$ & $\begin{array}{r}25 \cdot 0 \\
3 \cdot 4 \\
2 \cdot 7\end{array}$ \\
\hline
\end{tabular}

Table 5 Behaviour by ethnic group

\begin{tabular}{|c|c|c|c|}
\hline & $\begin{array}{l}\text { Caucasian } \\
(n=1524)\end{array}$ & $\begin{array}{l}\text { Afro-Caribbean } \\
(n=294)\end{array}$ & $p$ \\
\hline Coitarche (mean) & $17.59 \mathrm{yrs}$ & $17 \cdot 23 \mathrm{yrs}$ & 0.0001 \\
\hline $\begin{array}{l}\text { Number of partners (mean) } \\
\text { in past year } \\
\text { in lifetime }\end{array}$ & $\begin{array}{r}1 \cdot 80 \\
10 \cdot 34\end{array}$ & $\begin{array}{l}1 \cdot 60 \\
5 \cdot 18\end{array}$ & $\begin{array}{l}0.24 \\
0.02\end{array}$ \\
\hline $\begin{array}{l}\text { Orogenital sex (ever) } \\
\text { penetration (\%) } \\
\text { ejaculation (\%) }\end{array}$ & $\begin{array}{l}85 \cdot 9 \\
50 \cdot 9\end{array}$ & $\begin{array}{l}58 \cdot 0 \\
19 \cdot 7\end{array}$ & $\begin{array}{l}<0.0001 \\
<0.0001\end{array}$ \\
\hline $\begin{array}{l}\text { Anal intercourse (ever) } \\
\text { penetration (\%) } \\
\text { ejaculation (\%) }\end{array}$ & $\begin{array}{r}20 \cdot 0 \\
9.9\end{array}$ & $\begin{array}{l}9 \cdot 1 \\
4 \cdot 7\end{array}$ & $\begin{array}{l}0.0003 \\
0.03\end{array}$ \\
\hline $\begin{array}{l}\text { Non-regular partner(s) } \\
\text { in past year }\end{array}$ & $40 \cdot 1$ & $34 \cdot 6$ & $0 \cdot 17$ \\
\hline \multicolumn{4}{|l|}{ Condom-use } \\
\hline $\begin{array}{l}\text { With regular partner(s) } \\
\text { always }(\%) \\
\text { never }(\%)\end{array}$ & $\begin{array}{l}11 \cdot 9 \\
46 \cdot 1\end{array}$ & $\begin{array}{r}9 \cdot 5 \\
51 \cdot 1\end{array}$ & $\begin{array}{l}0 \cdot 39 \\
0 \cdot 23\end{array}$ \\
\hline $\begin{array}{l}\text { With non-regular partner(s) } \\
\text { always }(\%) \\
\text { never }(\%)\end{array}$ & $\begin{array}{l}35 \cdot 8 \\
24 \cdot 3\end{array}$ & $\begin{array}{l}27 \cdot 3 \\
34 \cdot 8\end{array}$ & $\begin{array}{l}0 \cdot 22 \\
0 \cdot 92\end{array}$ \\
\hline $\begin{array}{l}\text { HIV risk behaviours (\%) } \\
\text { One or more } \\
\text { Sex with African (\%) } \\
\text { Sex with IVDU (\%) } \\
\text { One/more STD (\%) } \\
\text { Genital herpes (\%) } \\
\text { Gonorrhoea (\%) }\end{array}$ & $\begin{array}{l}21 \cdot 4 \\
8 \cdot 0 \\
6 \cdot 9 \\
27 \cdot 9 \\
4 \cdot 6 \\
3 \cdot 2\end{array}$ & $\begin{array}{r}29 \cdot 5 \\
23 \cdot 4 \\
1.5 \\
29 \cdot 8 \\
1.0 \\
10 \cdot 6\end{array}$ & $\begin{array}{l}0.01 \\
<0.0001 \\
0.005 \\
0.83 \\
0.02 \\
0.0001\end{array}$ \\
\hline
\end{tabular}

Table 6 Coitarche, socio-economic status and ethnicity

\begin{tabular}{llll}
\hline & $\begin{array}{l}\text { Caucasian } \\
(n=1524)\end{array}$ & $\begin{array}{l}\text { Afro-Caribbean } \\
(n=294)\end{array}$ & $p$ \\
\hline Class 1 (mean in years) & 18.00 & 18.00 & 0.991 \\
Class 2 (mean in years) & 17.59 & 17.24 & 0.328 \\
Class 3 (mean in years) & 17.55 & 16.09 & 0.003 \\
\hline
\end{tabular}

did those in the FPC group ( $p=0.021)$.

Significantly more women in the GUM group reported one or more past episodes of STD than did women in either the FPC $(p<0.0001)$ or TOP group $(p=0.0001)$.

\section{Comparison between socio-economic groups}

Data from all three clinic populations were pooled and analysed according to socioeconomic group (Table 4).

Coitarche was at a significantly older age in women in class 1 than in those in class 2 (p < $0.0001)$ and class $3(p<0.0001)$. Orogenital sex, both penetration and to ejaculation, had been practised by significantly more women in class 1 than by those in class $2(p=0.0001$ and $p=0.003$ for two activities respectively) and class 3 ( $p<0.0001$ for both activities).

There was no significant difference in the number of women in the three classes who reported any one individual HIV risk-behaviour. Overall there was no significant difference in the number of women who reported a prior STD. However, on analysing for individual diseases, significantly more class 1 than class 2 women had had genital herpes $(p=$ 0.03 ) and significantly more class 1 than class 3 women had had trichomoniasis $(p=0.02)$.

Comparisons between ethnic groups

Data from all groups were analysed according to ethnicity (table 5). Age at first intercourse was significantly younger in Afro-Caribbean women. As coitarche had also been found to be younger in the lower socio-economic groups and as black women may, on average, be more often socially disadvantaged than white women, an analysis of coitarche between the two groups was performed, controlling for socio-economic status (table 6). The ethnic difference was no longer significant in two out of three socio-economic groups.

Caucasian women reported significantly more lifetime sexual partners than did AfroCaribbean women. This was not attributable to the Caucasian women being older, and hence their having been sexually active for longer, as thier mean age was less than that of the Afro-Caribbean women (25.3 and 27.1 years respectively).

Orogenital sex had been practised significantly more often, both penetration and to ejaculation, by Caucasian women than by Afro-Caribbean women. As orogenital sex had also been found to be more frequently performed by women in the highest socioeconomic group an analysis was performed controlling for class (table 7). This demonstrates that there is an independent effect of ethnicity on the sexual behaviour, but also a clear effect of socio-economic status within each ethnic group.

Anal intercourse has also been practised significantly more often, both penetration and to ejaculation, by Caucasian women than by Afro-Caribbean women.

Significantly more Afro-Caribbean than Caucasian women reported one or more major risk-behaviours for HIV infection. 
Table 7 Orogenital sex, socio-economic status and ethnicity

\begin{tabular}{lllr}
\hline & $\begin{array}{l}\text { Caucasian } \\
(n=1524)\end{array}$ & $\begin{array}{l}\text { Afro-Caribbean } \\
(n=294)\end{array}$ & $p$ \\
\hline $\begin{array}{l}\text { Penetration (\%) } \\
\text { Class 1 }\end{array}$ & & & \\
Class 2 & 93.2 & 71.4 & $<0.0001$ \\
Class 3 & 85.4 & 63.3 & 0.0004 \\
Ejaculation (\%) & 81.5 & 38.7 & $<0.0001$ \\
Class 1 & & & 0.0163 \\
Class 2 & 59.1 & 34.5 & 0.0006 \\
Class 3 & 50.0 & 21.7 & 0.0253 \\
\hline
\end{tabular}

Table 8 Past genital herpes, socio-economic status and ethnicity

\begin{tabular}{llll}
\hline & $\begin{array}{l}\text { Caucasian } \\
(n=1524)\end{array}$ & $\begin{array}{l}\text { Afro-Caribbean } \\
(n=294)\end{array}$ & $p$ \\
\hline Class 1 & 6.4 & 2.8 & 0.02 \\
Class 2 & 2.9 & 1.9 & 0.5 \\
Class 3 & 3.2 & 0 & 0.004 \\
\hline
\end{tabular}

On analysing individual risk behaviours this was found to be a result of more AfroCaribbean than Caucasian women having had intercourse with a man from sub-Saharan Africa. The only other behaviour that was significantly different between the two groups was intercourse with an intravenous drug user which was reported more often by Caucasian than by Afro-Caribbean women.

Although overall rates of STD were no different between the two groups, further analysis revealed that two individual STD were reported at significantly different frequencies; genital herpes more commonly by Caucasian than by Afro-Caribbean women and gonorrhoea more frequently by Afro-Caribbean than by Caucasian women. As prior genital herpes had also been found to be more frequent in women in the highest socioeconomic group, an analysis was performed controlling for class (table 8). Genital herpes was significantly more common amongst Caucasian women in classes 1 and 2.

\section{Discussion}

That the OCP was the most popular form of contraception in two of the three groups is significant since it is known to almost double the risk of chlamydial infection in women. ${ }^{7}$

The results of this study indicate that the sexual behaviour of women in the three clinical situations studied is strikingly similar. This has been demonstrated by previous studies conducted in both this country and the USA, ${ }^{28}$ thus refuting the popular belief that women attending an STD clinic are uniquely promiscuous.

Mean age at coitarche varied little between the three groups (17.3-17.9 years). Closely similar values have been obtained in previous studies on women attending a GUM clinic and a family planning clinic in the $\mathrm{UK}^{24}$ and also in random population studies conducted in the UK, Sweden and France. ${ }^{19} 10$

Similar, rather low numbers of sexual partners were reported in all groups: median values being 1-2 and 4-6 for partners in the past year and lifetime respectively. These results are compatible with those of previous studies on the sexual behaviour of UK women in a family planning clinic, an STD clinic and the general population, ${ }^{146}$ female students attending a college health service in the USA and women in a random sample of the French population, ${ }^{10}$ all of which found the median number of sexual partners in the previous year to be one.

Orogenital sex (fellatio) had been practised by a clear majority of women in each group $(63 \cdot 1-86 \cdot 1 \%)$ indicating that this behaviour constitutes a part of the normal contemporary sexual repertoire. This is relevant to the spread of STD as various infections can be spread by this route, for example gonorrhoea and herpes simplex virus (HSV) infection. It is also directly relevant to the clinician since fellatio is associated with pharyngeal infection with Neisseria gonorrhoeae ${ }^{11}$ and so a throat culture may be necessary to exclude gonorrhoea.

The findings that over half of the women in each group (54.8-68.9\%) reported having had a casual sexual partner in the preceding 12 months, and that only about a third $(31 \cdot 3-39 \cdot 7 \%)$ always used a condom, demonstrate considerable potential for STD transmission.

Approximately one in five women in each group (18.6-23.9\%) reported one or more HIV risk behaviours. Concern about possible transmission of HIV is increased by the findings that substantial numbers of women had had an STD (21.7-32.5\%) or had practised anal intercourse $(15 \cdot 4-20 \cdot 2 \%)$ both of which have been shown to increase heterosexual HIV transmission independently, ${ }^{12-14}$ and by the observation that so few women always used a condom with their partners, both regular and non-regular.

Certain aspects of sexual behaviour were found to be dependent on socio-economic status. Thus coitarche occurred earlier in women of lower social class. This has been reported previously ${ }^{15-17}$ and is a contributory factor to the higher incidence of cervical carcinoma in this group, ${ }^{18-20}$ whereas to our knowledge the strong effect of socioeconomic status upon the practice of fellatio has not been described before. The greater incidence of clinical genital herpes amongst women of higher social class may be a result of less frequent prior exposure to $\mathrm{HSV}-1 . .^{22-28}$ Of equal significance are the many parameters that did not vary with socio-economic status such as prior STD and number of sexual partners. These findings are in agreement with earlier work ${ }^{11617}$ and indicate that STD are important to women from all backgrounds.

Other behaviours were influenced by ethnic origin. Thus Caucasian women reported more sexual partners than Afro-Caribbean women and were more likely to have practised orogenital and anal sex, in keeping with other studies. ${ }^{2}$ They also admitted more frequently to a history of genital herpes and to having had intercourse with a user of intravenous drugs. 
Conversely, more black women reported one or more HIV risk behaviours and this was entirely due to more of them having had intercourse with a man from sub-Saharan Africa. As has been found in studies in the USA $^{28-30}$ black women were more likely to have had gonorrhoea and this can not be explained by the data collected in this study. It presumably relates to the behaviour of their partners.

The finding that $25.3 \%$ of women in the GUM group were not using regular contraception shows the need for better delivery of family planning to this group. Conversely, the sexually active, young, predominantly unmarried women attending clinics for family planning or abortion appear to be at considerable risk of STD including HIV.

In conclusion, closer integration between clinical disciplines is essential if a comprehensive sexual health service is to be provided for women.

1 Johnson AM, Wadsworth J, Wellings $\mathrm{K}$, et al. Sexual lifestyles and HIV risk. Nature 1992;360:410-2.

2 Evans BA, Bond RA, Macrae KD. Sexual behaviour in women attending a genitourinary medicine clinic. Genitourin Med 1988;64:43-8.

3 Evans BA, McCormack SM, Bond RA, et al. Human immunodeficiency virus infection, hepatitis $\mathbf{B}$ virus infection and sexual behaviour of women attending a infection and sexual behaviour of women attending

4 UK Family Planning Research Network. Patterns of sexual behaviour among sexually experienced women attending family planning clinics in England, Scotlan and Wales. Br f Family Planning 1988;14:74-82.

5 De Buono BA, Zinner SH, Daamen M, et al. Sexua behaviour of college women in 1975, 1986, and 1989 . $N$ Engl f Med 1990;322:821-5.

6 Evans BA, McCormack SM, Bond RA, et al. Trends in sexual behaviour and HIV testing among women presenting at a cenitourinary medicine clinic during the advent of AIDS. Genitourin Med 1991;67:194-8.

7 Cottingham J, Hunter D. Chlamydia trachomatis and oral contraceptive use; a quantitative review. Genitourin Med 1992;68:209-16

8 Wasser SC, Aral SO, Reed DS, et al. Assessing behavioural risk for HIV infection in family-planning and STD clinics. Sex Transm Dis 1989;16:178-83.

9 Giesecke J, Scalia-Tomba G, Gothberg M, et al. Sexual behaviour related to the spread of sexually transmitted diseases-a population-based survey. Int $\mathfrak{f} S T D \mathcal{E}$ AIDS 1992;3:255-60.

10 ACSF Investigators. AIDS and sexual behaviour in
France. Nature 1992;360:407-9.

11 Sackel SG, Alpert S, Fiumara NI, et al. Orogenital contact and the isolation of Neisseria gonorrhoeae Mycoplasma hominis and Ureaplasma urealyticum from the pharynx. Sex Transm Dis 1979;6:64-8.

12 Padian N, Marquis L, Francis DP, et al. Male-to-female transmission of human immunodeficiency virus. $\mathfrak{F} A M A$ 1987;258:788-90.

13 European Study Group. Risk factors for male to female transmission of HIV. BMF 1989;298:411-23.

14 Johnson AM, Laga M. Heterosexual transmission of HIV. AIDS 1988;2(suppl.1)s49-s56.

15 Brown S, Vessey M, Harris R. Social class, sexual habits and cancer of the cervix. Community Medicine 1984, 6:281-6.

16 Mant D, Vessey M, Loudon N. Social class differences in sexual behaviour and cervical cancer. Community sexual behaviour and

17 Garde K, Lunde I. Influence of social status on female sexual behaviour. A random sample study of 40 -year old Danish women. Scand $\mathcal{f}$ Prim Health Care 1984;1:5-10.

18 Rotkin ID, Cameron JR. Clusters of variables influencing risk of cervical cancer. Cancer 1968;21:663-71.

19 Harris RWC, Brinton LA, Cowdell $\mathrm{RH}$ et al. Characteristics of women with dysplasia or carcinoma in situ of the cervix uteri. Br f Cancer 1980;42:359-69.

$20 \mathrm{La}$ Vecchia C, Franceschi S, Descarli A, et al. Sexual factors, venereal diseases, and the risk of intra-epithelial tors, venereal diseases, and the risk of intra-epithelial

21 Ades AE, Peckham CS, Dale GE, et al. Prevalence of antibodies to herpes simplex virus types 1 and 2 in pregnant women, and estimated rates of infection. $\mathcal{f}$ Epidemio Comm Health 1989;43:53-60.

22 Gibson J, Hornung CA, Alexander GR, et al. A cross-sectional study of herpes simplex virus types 1 and 2 in college students: occurrence and determinants of infection. F Infect Dis 1990;162:306-12.

23 Breinig MK, Kingsley LA, Armstrong JA, et al. Epidemiology of genital herpes in Pittsburgh: serologic, sexual and racial correlates of apparent and inapparent herpes simplex infections. $\mathcal{f}$ Infect Dis 1990;162: herpes sim-305.

24 Adler-Storthz K, Dreesman GR, Kaufman RH, et al. A prospective study of herpes simplex virus infection in a defined population in Houston, Texas. Am $\mathcal{F}$ Obste Gynecol 1985;151:582-6.

25 Kulhanjian JA, Soroush V, Au DS, et al. Identification of women at unsuspected risk of primary infection with herpes simplex virus type 2 during pregnancy. $N$ Engl Med 1992;326:916-20.

26 Rawls WE, Campione-Piccardo J. Epidemiology of herpes simplex virus type 1 and type 2 infections. In: Nahmias AJ, Dowdle WR, Schinazi RF (eds). The Human Herpesviruses Amsterdam, Elsevier, 1981 .

27 Mertz GJ, Benedetti J, Ashley R, et al. Risk factors for the sexual transmission of genital herpes. Ann Intern Med 1992;116:197-202.

28 Barnes RC, Holmes KK. Epidemiology of gonorrhoea: current perspectives. Epidemiol Rev 1984;6:1-30.

29 Rothenberg RB, Potterat J. Strategies for management of sex partners. In: Holmes KK, Mardh P-A, Sparling PF et al. (eds). Sexually Transmitted Diseases (2nd ed.) New York, McGraw-Hill, 1990.

30 Brooks GF, Darrow WW, Day JA. Repeated gonorrhoea an analysis of importance and risk factors. $\mathcal{F}$ Infect $D$ is 1978;137:161-9. 